\title{
Pengukuran kualitas layanan website Universitas Tadulako menggunakan metode WebQual
}

\author{
Suci Ramadhani Arifin \\ Teknik Informatika, Universitas Tadulako, Palu, Indonesia \\ email:scrmd88@gmail.com
}

\section{N F O A R T I K E L}

\section{Sejarah artikel:}

Menerima 19 Agustus 2018

Revisi 30 Agustus 2018

Diterima 31 Agustus 2018

Online 3 September 2018

\section{Kata kunci:}

diagram kartesius

Importance Performance

Analysis

kualitas layanan website

Universitas Tadulako

WebQual

\section{Keywords:}

cartesius diagram

Importance Performance

Analysis

service quality website

Tadulako University

WebQual

Style APA dalam mensitasi artikel ini:

Pengukuran kualitas

layanan website Universitas

Tadulako menggunakan metode WebQual. Register: Jurnal Ilmiah Teknologi Sistem Informasi, 4(2), 125-136.
Arifin, S. R. (2018)

\begin{abstract}
ABSTRAK
Keberhasilan layanan website Universitas Tadulako sampai saat ini belum diketahui, karena belum pernah dilakukan pengukuran sejak diimplementasikan. Tingkat keberhasilan layanan website Universitas Tadulako dapat dilihat dari kesesuaian antara persepsi dan harapan pengguna website. Penelitian ini dilakukan dengan tujuan untuk mengetahui perbedaan antara persepsi aktual dan harapan ideal mahasiswa terhadap kualitas layanan website Universitas Tadulako yang diukur berdasarkan dimensi kualitas WebQual 4.0. Data dikumpulkan dengan menggunakan kuesioner dengan teknik Simple Random Sampling. Data kemudian dianalisis dengan menggunakan teknik Analisis Perbedaan (uji beda $t$ ) dan Importance Performance Analysis (IPA). Hasil penelitian membuktikan bahwa terdapat perbedaan (gap) antara persepsi aktual dan harapan ideal mahasiswa pada masing-masing dimensi kualitas website, di mana nilai persepsi lebih kecil dibandingkan dengan harapan mahasiswa. Gap paling kecil terletak pada dimensi kegunaan (usability) dengan tingkat kesesuaian sebesar $85 \%$ yang mengindikasikan bahwa layanan website Universitas Tadulako cukup berhasil pada kegunaan wesbite. Gap paling besar terletak pada dimensi kualitas interaksi layanan dengan tingkat kesesuaian sebesar 73,52\% yang mengindikasikan bahwa layanan website Universitas Tadulako yang belum memenuhi harapan ideal mahasiswa, terutama dari kualitas interaksi layanan website. Hasil penelitian dapat menjadi acuan bagi pihak manajemen website untuk mengembangkan website yang lebih baik agar memenuhi harapan pengguna.
\end{abstract}

\section{ABSTRACT}

The success of Tadulako University website service is still unknown because it has never been measured since it was implemented. The success rate of Tadulako University website service can be seen from the fitness between the perception and expectations of website users. This research was conducted to find out thegap value between student's actual perception and ideal expectations of Tadulako University website services quality which is measured by WebQual 4.0 dimensions. Data was collected using a questionnaire with simple random sampling technique. The collected data were analyzed using differences analysis and Importance Performance Analysis (IPA). The results showed that there are differences (gap) between student's actual perception and ideal expectations at each of dimension of website quality, where the perception's value is smaller than the expectations. The smallest gap lies in the usability dimension with a suitability level of $85 \%$ that indicates Tadulako University website services quality quite successful on usability. The biggest gap lies in the service interaction quality dimension with a suitability level of $73.52 \%$ that indicates Tadulako University website services quality has not met the student's ideal expectations especially from service interaction quality. The results of the study can be a reference for the management of the website to develop a better website in order to meet user expectations.

(c) 2018 Register: Jurnal IImiah Teknologi Sistem Informasi. Semua hak cipta dilindungi undang-undang.

\section{Pendahuluan}

Universitas Tadulako (Untad) adalah perguruan tinggi negeri yang terletak di Kota Palu, Indonesia. Universitas Tadulako (Untad) menempati peringkat ke 38 dari daftar 100 peringkat perguruan tinggi

Pengukuran kualitas layanan website Universitas Tadulako menggunakan ... http://doi.org/10.26594/register.v4i2.1277

(C) 2018 Register: Jurnal IImiah Teknologi Sistem Informasi. Semua hak cipta dilindungi undang-undang. 
non-politeknik di Indonesia tahun 2017 (Dikti, 2018). Lebih lanjut, Untad berada di peringkat ke 3 di bawah Universitas Hasanuddin (Unhas) yang menempati peringkat ke 11, dan Universitas Negeri Makassar (UNM) pada peringkat ke 31 untuk peringkat Perguruan Tinggi Negeri (PTN) di kawasan timur Indonesia (Bakri, 2016).

Untad berusaha untuk terus menyediakan pelayanan terbaik khususnya kepada mahasiswa Untad. Pelayanan terbaik tersebut dilaksanakan dalam semua bidang, salah satunya pada bidang teknologi informasi dengan mengembangkan website resmi Universitas Tadulako yang dapat diakses di www.untad.ac.id.

Keberadaan teknologi informasi sangat berguna untuk memudahkan pekerjaan manusia. Suatu pekerjaan dapat diselesaikan dengan lebih efektif dan efisien dengan adanya teknologi informasi. Saat ini, penerapan teknologi informasi telah banyak dilaksanakan di berbagai instansi pemerintah maupun swasta (Jannah \& Arifin, 2015).

Website Untad merupakan layanan informasi berbasis web yang dibangun serta dikembangkan oleh pihak Untad, website tersebut di dalamnya berisi informasi-informasi seputar Untad, mulai dari informasi mengenai kegiatan dan perkembangan universitas secara umum, hingga informasi akademik. Website ini juga menyediakan beberapa pelayanan online (online service) yang dapat diakses langsung oleh mahasiswa seperti E-Learning, Digital Library, Tracer Study, dan beberapa layanan online lainnya (Tadulako, 2015).

Penerapan layanan berbasis web perlu didukung adanya tingkat kualitas layanan yang baik kepada penggunanya. Selain kualitas produk, kualitas dari layanan yang disediakan juga merupakan hal yang penting untuk meyakinkan para pengguna agar tetap menggunakan layanan yang diberikan. Lebih lanjut, kualitas layanan menjadi sesuatu yang penting khususnya ketika institusi pendidikan tinggi berhadapan dengan para pengguna yang menuntut atau membutuhkan kesempurnaan dari layanan yang diberikan (Kesuma, 2014).

Sejak website Untad diimplementasikan, belum pernah dilakukan pengukuran terhadap kualitas website berdasarkan persepsi pengguna website, sehingga keberhasilan layanan website Untad sampai saat ini belum diketahui. Berdasarkan hal tersebut, maka perlu dilakukan suatu penelitian untuk mengukur kualitas layanan website Untad dari persepsi pengguna, penelitian ini bertujuan untuk mengetahui sejauh mana tingkat keberhasilan layanan website Untad dilihat dari kesesuaian antara persepsi dan harapan pengguna website. Hasil pengukuran tersebut diharapkan dapat berguna untuk meningkatkan layanan berbasis web bagi pengguna di lingkungan perguruan tinggi.

\section{State of the Art}

Penelitian yang dilakukan menggunakan metode WebQual yang merupakan metode atau alat untuk menilai kualitas website menggunakan persepsi pengguna. Indeks WebQual memberikan rating keseluruhan website berdasarkan persepsi pengguna. Instrumen WebQual telah dikembangkan secara iteratif melalui aplikasi dalam berbagai domain, termasuk dalam domain akademik (Tarigan, 2008). Secara garis besar penelitian ini mengacu pada penelitian terdahulu yang telah dilakukan oleh Barnes dan Vidgen sebagai pengembang WebQual (Barnes \& Vidgen, 2002; Barnes \& Vidgen, 2003; Barnes \& Vidgen, 2005).

Barnes dan Vidgen lebih dahulu telah melaksanakan penelitian menggunakan metode yang telah Barnes dan Vidgen kembangkan, metode tersebut yaitu WebQual 4.0 untuk melakukan penilaian pada beberapa jenis website, termasuk website non pemerintah (e-commerce) dan website pemerintahan (egovernment) berdasarkan usability quality, information quality, dan service interaction quality (Arifin, 2015).

Beberapa penelitian lain yang menggunakan metode WebQual 4.0 untuk menilai kualitas sebuah website di bidang akademik (perguruan tinggi) diantaranya dilakukan oleh Sujono dan Santoso (2017) yang melakukan penelitian untuk mengukur kualitas E-Learning Universitas KH. A. Wahab Hasbullah. Penelitian menggunakan variabel berdasarkan metode WebQual seperti yang dilakukan penelitian sebelumnya oleh Barnes dan Vidgen yang terdiri atas dimensi usability, information dan service interaction. Sujono dan Santoso (2017) kemudian menyimpulkan bahwa E-Learning Universitas KH. A. Wahab Hasbullah paling berhasil pada dimensi Usability.

Penelitian lain dilakukan oleh Monalisa (2016) menggunakan metode WebQual 4.0 untuk menganalisis kualitas layanan website UIN Suska Riau. Monalisa menemukan bahwa dimensi service 
interaction memiliki pengaruh positif yang paling besar terhadap kepuasan mahasiswa. Penelitian selanjutnya telah memperluas dan mengembangkan metode WebQual 4.0 menjadi beberapa variabel WebQual untuk menilai kualitas sebuah website. Arifin (2015) melakukan penilaian terhadap kualitas layanan website Universitas Hasanuddin menggunakan metode WebQual 4.0 yang telah dimodifikasi dengan menambahkan dimensi kualitas antarmuka pengguna dengan tiga dimensi utama WebQual 4.0. Hasil penelitian Arifin (2015) membuktikan bahwa, layanan website Universitas Hasanuddin cukup berhasil pada kualitas informasi dan kualitas antarmuka pengguna belum memenuhi harapan ideal mahasiswa.

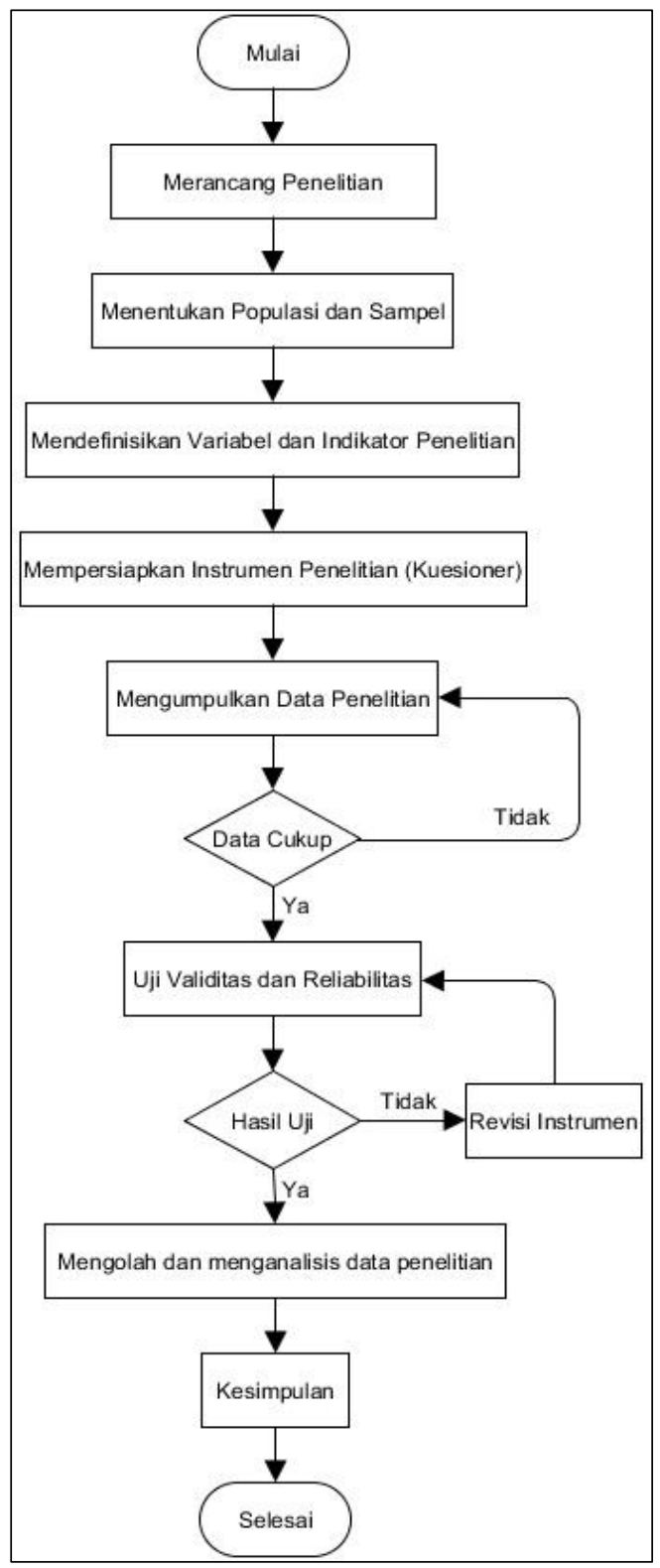

Gambar 1. Alur penelitian

Dalam penelitian ini, kualitas layanan website Universitas Tadulako diukur menggunakan metode WebQual 4.0 yang menitikberatkan pada eksplorasi kualitas layanan website berdasarkan persepsi mutu layanan website yang dirasakan (actual) dengan tingkat harapan (ideal) yang diinginkan oleh pengguna website. Penelitian yang dilakukan akan mengadopsi framework penelitian Arifin (2015). Penelitian ini menggunakan metode WebQual versi 4.0 yang telah dimodifikasi dengan menambahkan dimensi kualitas antarmuka pengguna (user interface quality) dengan tiga dimensi utama WebQual 4.0, yaitu kualitas kegunaan (usability quality), kualitas informasi (information quality) dan kualitas layanan interaksi (service interaction quality).

User interface (UI) dari sistem akses publik adalah fitur penting yang berdampak pada kinerja suatu sistem. Oleh karena itu, kualitas antarmuka pengguna (user interface quality) sebuah website 
penting untuk diukur kualitasnya karena user interface berhubungan dengan daya tarik visual website, pengguna akan melihat tampilan website sebagai interaksi pertama sebelum menyusuri website lebih dalam (Peng, Ramaiah, \& Foo, 2004).

\section{Metode Penelitian}

Penelitian ini menggunakan metode penelitian deskriptif kuantitatif dengan pendekatan survei. Populasi dalam penelitian ini adalah seluruh mahasiswa program S1 Universitas Tadulako yang terbagi ke dalam 11 fakultas yang ada di Universitas Tadulako. Jumlah sampel ditetapkan sebanyak 150 responden. Selanjutnya penentuan sampel tiap fakultas menggunakan teknik simple random sampling.

Data primer pada penelitian ini diperoleh dari kuesioner yang diberikan kepada responden sebagai instrumen penelitian yang dapat dilihat pada Tabel 1. Variabel yang digunakan dalam penelitian ini adalah kriteria pengukuran kualitas website berdasar pendekatan WebQual 4.0 modifikasi Arifin (2015) yang terdiri atas kualitas kegunaan (usability quality), kualitas informasi (information quality), kualitas layanan interaksi (service interaction quality) dan kualitas antarmuka pengguna (user interface quality) yang dilihat dari dua perspektif yaitu kualitas aktual yang dirasakan (performance) dan kualitas ideal yang diinginkan (importance).

Tabel 1. Instrumen penelitian (Arifin, 2015)

\begin{tabular}{|c|c|c|c|}
\hline Variabel & Sumber & Kode & Indikator \\
\hline Kualitas & WebQual 4.0 & IFQ1 & Website menyediakan informasi yang akurat \\
\hline \multirow[t]{6}{*}{ Informasi } & & IFQ2 & Website menyediakan informasi yang terpercaya \\
\hline & & IFQ3 & Website menyediakan informasi tepat waktu \\
\hline & & IFQ4 & Website menyediakan informasi yang relevan \\
\hline & & IFQ5 & Website menyediakan informasi yang mudah dimengerti \\
\hline & & IFQ6 & Website menyediakan informasi yang detail \\
\hline & & IFQ7 & Website menyajikan informasi dalam format yang tepat \\
\hline Kualitas & WebQual 4.0 & SIQ8 & Pengguna merasa aman ketika melakukan transaksi \\
\hline Interaksi & & SIQ9 & Pengguna merasa aman terhadap informasi pribadi \\
\hline \multirow[t]{4}{*}{ Layanan } & & SIQ10 & Website memberikan ruang untuk personalisasi \\
\hline & & SIQ11 & Website memberikan ruang untuk komunitas \\
\hline & & SIQ12 & $\begin{array}{l}\text { Website memberikan kemudahan untuk berkomunikasi dengan } \\
\text { organisasi }\end{array}$ \\
\hline & & SIQ13 & $\begin{array}{l}\text { Pengguna merasa yakin bahwa layanan yang diterima sesuai } \\
\text { dengan yang dijanjikan }\end{array}$ \\
\hline Kualitas & Hasan (2014) & UIQ14 & Website menggunakan gambar yang tepat \\
\hline Antarmuka & & UIQ15 & Website menggunakan font (huruf) yang sesuai \\
\hline \multirow[t]{6}{*}{ Pengguna } & & UIQ16 & Website menggunakan warna yang sesuai \\
\hline & & UIQ17 & Website menggunakan desain halaman yang sesuai \\
\hline & & UIQ18 & Link pada website bekerja dengan baik \\
\hline & & UIQ19 & Kecepatan download pada halaman website \\
\hline & Sutcliffe (2001) & UIQ20 & Website memiliki tata letak yang terstruktur dan konsisten \\
\hline & & UIQ21 & Website mencerminkan identitas universitas \\
\hline \multirow[t]{7}{*}{ Usability } & WebQual 4.0 & USQ22 & Pengguna dengan mudah dapat belajar menggunakan website \\
\hline & & USQ23 & Interaksi pengguna dengan website jelas dan dapat dimengerti \\
\hline & & USQ24 & Website mudah untuk dinavigasi \\
\hline & & USQ25 & Website mudah untuk digunakan \\
\hline & & USQ26 & Website mengandung nilai kompetensi \\
\hline & & USQ27 & Website menciptakan pengalaman positif bagi pengguna \\
\hline & & USQ28 & Website memiliki tampilan yang menarik \\
\hline
\end{tabular}

Alur dari penelitian akan bergantung dari hasil uji validitas dan reliabilitas. Jika instrumen penelitian tidak valid dan reliabel, maka dilakukan revisi instrumen. Untuk melakukan analisis validitas data digunakan uji korelasi product moment. Suatu indikator dikatakan valid apabila besarnya koefisien korelasi product moment melebihi 0,3 (Siregar, 2013). Sedangkan uji reliabilitas dilakukan untuk mengukur sejauh mana hasil suatu pengukuran dapat dipercaya. Uji reliabilitas dilakukan dengan teknik Alpha Cronbach $(\alpha)$. Suatu instrumen penelitian dikatakan reliable bila koefisien reliabilitas $>0,6$ (Siregar, 2013). Gambar 1 berisi bagan alur mengenai bagaimana penelitian dilangsungkan mulai dari rancangan penelitian sampai kepada kesimpulan akhir dari penelitian. Data yang terkumpul akan 
diolah menggunakan teknik Importance Performance Analysis (IPA) untuk membandingkan penilaian mahasiswa terhadap pentingnya kualitas layanan (importance) dengan tingkat kualitas kinerja layanan (performance) website Untad.

\section{Hasil dan Pembahasan}

\subsection{Uji validitas dan reliabilitas}

Sebelum mengolah data kuesioner, terlebih dahulu dilakukan uji validitas dan realibilitas dari berdasarkan pertanyaan pada instrumen penelitian pada Tabel 1. Hasil dari uji validitas dan reliabilitas dari masing-masing variabel dijelaskan pada Tabel 2. Perhitungan uji validitas dan reliabilitas menggunakan software statistik SPSS versi 21 . Hasil uji validitas instrumen yang telah diolah menggunakan uji korelasi product moment pada Tabel 2 menunjukkan bahwa seluruh atribut pertanyaan pada instrumen adalah valid karena berada di atas 0,3 .

Tabel 2. Hasil uji validitas dan reliabilitas

\begin{tabular}{|c|c|c|c|c|c|c|}
\hline \multirow[b]{2}{*}{ Indikator } & \multicolumn{3}{|c|}{ Persepsi } & \multicolumn{3}{|c|}{ Harapan } \\
\hline & $\begin{array}{c}\text { Koef. } \\
\text { Korelasi }\end{array}$ & Sig. & $\begin{array}{c}\text { Alpha } \\
\text { Cronbach }(\alpha)\end{array}$ & $\begin{array}{c}\text { Koef. } \\
\text { Korelasi }\end{array}$ & Sig. & $\begin{array}{c}\text { Alpha } \\
\text { Cronbach }(\alpha)\end{array}$ \\
\hline IFQ1 & 0,764 & 0,000 & 0,780 & 0,732 & 0,000 & 0,791 \\
\hline IFQ2 & 0,695 & 0,000 & & 0,718 & 0,000 & \\
\hline IFQ3 & 0,697 & 0,000 & & 0,797 & 0,000 & \\
\hline IFQ4 & 0,693 & 0,000 & & 0,826 & 0,000 & \\
\hline IFQ5 & 0,726 & 0,000 & & 0,825 & 0,000 & \\
\hline IFQ6 & 0,752 & 0,000 & & 0,809 & 0,000 & \\
\hline IFQ7 & 0,777 & 0,000 & & 0,799 & 0,000 & \\
\hline SIQ8 & 0,734 & 0,000 & 0,775 & 0,873 & 0,000 & 0,806 \\
\hline SIQ9 & 0,701 & 0,000 & & 0,842 & 0,000 & \\
\hline SIQ10 & 0,704 & 0,000 & & 0,845 & 0,000 & \\
\hline SIQ11 & 0,628 & 0,000 & & 0,809 & 0,000 & \\
\hline SIQ12 & 0,735 & 0,000 & & 0,827 & 0,000 & \\
\hline SIQ13 & 0,667 & 0,000 & & 0,846 & 0,000 & \\
\hline UIQ14 & 0,826 & 0,000 & 0,781 & 0,793 & 0,000 & 0,784 \\
\hline UIQ15 & 0,753 & 0,000 & & 0,772 & 0,000 & \\
\hline UIQ16 & 0,800 & 0,000 & & 0,754 & 0,000 & \\
\hline UIQ17 & 0,765 & 0,000 & 0,789 & 0,797 & 0,000 & 0,799 \\
\hline UIQ18 & 0,628 & 0,000 & & 0,758 & 0,000 & \\
\hline UIQ19 & 0,667 & 0,000 & & 0,712 & 0,000 & \\
\hline UIQ20 & 0,762 & 0,000 & & 0,871 & 0,000 & \\
\hline UIQ21 & 0,793 & 0,000 & & 0,709 & 0,000 & \\
\hline USQ22 & 0,739 & 0,000 & & 0,796 & 0,000 & \\
\hline USQ23 & 0,807 & 0,000 & & 0,894 & 0,000 & \\
\hline USQ24 & 0,809 & 0,000 & & 0,811 & 0,000 & \\
\hline USQ25 & 0,820 & 0,000 & & 0,881 & 0,000 & \\
\hline USQ26 & 0,712 & 0,000 & & 0,866 & 0,000 & \\
\hline USQ27 & 0,803 & 0,000 & & 0,868 & 0,000 & \\
\hline USQ28 & 0,736 & 0,000 & & 0,773 & 0,000 & \\
\hline
\end{tabular}

Sumber: Data primer yang diolah, 2018

Setelah dilakukan uji validitas dan seluruh alat ukur dinyatakan valid, maka selanjutnya dilakukan uji reliabilitas menggunakan teknik Alpha Cronbach $(\alpha)$. Berdasarkan Tabel 2 di atas dapat ditunjukkan bahwa nilai Alpha Cronbach $(\alpha)$ instrumen penelitian pada masing-masing indikator sama dengan atau lebih besar dari nilai yang disyaratkan yaitu sebesar 0,6. Dengan demikian dapat dikatakan bahwa keseluruhan item instrumen kuesioner valid dan reliabel karena telah memenuhi syarat minimal. Berdasarkan hasil dari uji validitas dan reliabilitas pada Tabel 2, maka disimpulkan jika kuesioner yang digunakan dalam penelitian ini layak untuk dijadikan sebagai instrumen dalam penelitian ini.

\subsection{Importance Performance Analysis}

Setelah dilakukan uji validitas dan reliabilitas instrumen kuesioner, maka selanjutnya dilakukan analisis berbasis Importance Performance Analysis (IPA) untuk menggambarkan tingkat kepuasan pengguna yaitu dengan mengetahui gap antara tingkat kepentingan (harapan) dan tingkat kinerja (persepsi) dari tiap variabel kualitas website berdasarkan pendekatan WebQual. 
Tahapan dalam metode IPA dimulai dengan menentukan tingkat kesesuaian antara tingkat kepentingan (harapan) dan kinerja (persepsi), kemudian menghitung rata-rata untuk setiap atribut yang dipersepsikan oleh pengguna dilanjutkan dengan menghitung rata-rata seluruh atribut kepentingan (harapan) dan kinerja (persepsi) yang akan menjadi batas dalam diagram kartesius. Terakhir adalah penjabaran tiap atribut ke dalam diagram kartesius (Arifin, 2015). Hasil perhitungan tingkat kesesuaian dan nilai rata-rata persepsi dan harapan ditunjukkan pada Tabel 3.

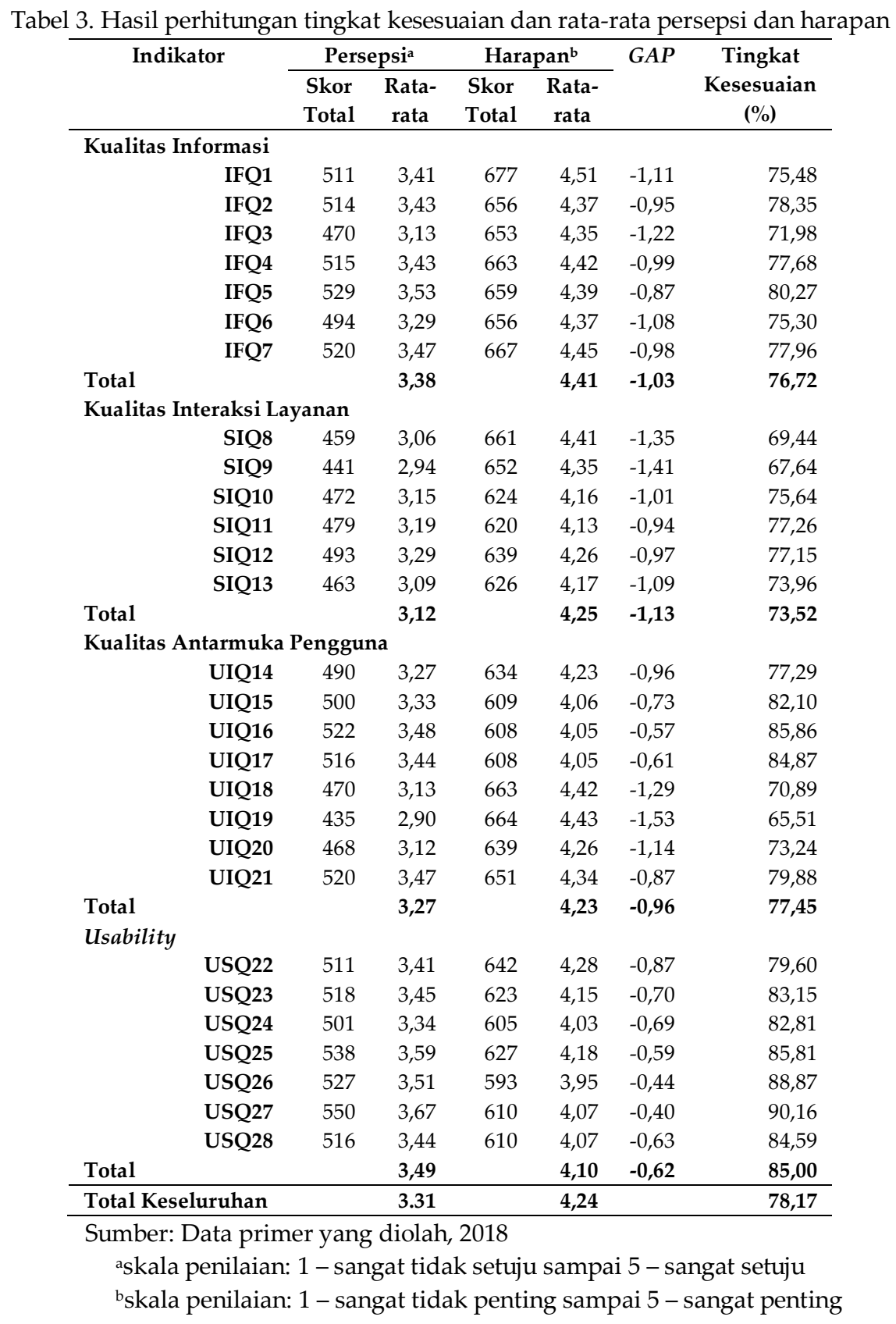

Berdasarkan hasil analisis tingkat kesesuaian terhadap indikator dimensi kualitas informasi pada Tabel 3, diketahui bahwa kesesuaian antara persepsi dan harapan yang paling rendah berada pada indikator IFQ3 (website menyediakan informasi tepat waktu) yaitu sebesar $71,98 \%$ dan kesesuaian antara persepsi dan harapan yang paling tinggi adalah indikator IFQ5 (website menyediakan informasi yang mudah dimengerti) yaitu sebesar $80,27 \%$. Secara keseluruhan, tingkat kesesuaian antara persepsi dan harapan mahasiswa terhadap kualitas informasi layanan website Untad adalah $76,72 \%$ yang termasuk ke dalam kategori kesesuaian sedang (60\% s/d 79\%).

Hasil analisis tingkat kesesuaian terhadap indikator dimensi kualitas interaksi layanan pada Tabel 3, diketahui bahwa kesesuaian antara persepsi dan harapan yang paling rendah berada pada indikator SIQ9 (pengguna merasa aman terhadap informasi pribadi) yaitu sebesar $67,64 \%$ dan 
kesesuaian antara persepsi dan harapan yang paling tinggi adalah indikator SIQ11 (website memberikan ruang untuk komunitas) yaitu sebesar $77,26 \%$. Secara keseluruhan, tingkat kesesuaian antara persepsi dan harapan mahasiswa terhadap kualitas interaksi layanan website Untad adalah $73,52 \%$ yang termasuk kedalam kategori kesesuaian sedang (60\% s/d 79\%).

Hasil analisis tingkat kesesuaian terhadap indikator dimensi kualitas antarmuka pengguna pada Tabel 3, diketahui bahwa kesesuaian antara persepsi dan harapan yang paling rendah berada pada indikator UIQ19 (kecepatan download pada halaman website) yaitu sebesar 65,51\% dan kesesuaian antara persepsi dan harapan yang paling tinggi adalah indikator UIQ16 (website menggunakan warna yang sesuai) yaitu sebesar $85,86 \%$. Secara keseluruhan, tingkat kesesuaian antara persepsi dan harapan mahasiswa terhadap kualitas antarmuka pengguna website Untad adalah 77,45\% yang termasuk kedalam kategori kesesuaian sedang (60\% s/d 79\%).

Berdasarkan hasil analisis tingkat kesesuaian terhadap indikator dimensi usability pada Tabel 3, diketahui bahwa kesesuaian antara persepsi dan harapan yang paling rendah berada pada indikator USQ22 (saya dengan mudah dapat belajar menggunakan website) yaitu sebesar 79,60\% dan kesesuaian antara persepsi dan harapan yang paling tinggi adalah indikator USQ27 (website menciptakan pengalaman positif bagi saya) yaitu sebesar $90,16 \%$. Secara keseluruhan, tingkat kesesuaian antara persepsi dan harapan mahasiswa terhadap usability website Untad adalah 85,00\% yang termasuk kedalam kategori kesesuaian tinggi ( $80 \%$ s/d 100\%).

Secara keseluruhan, berdasarkan Tabel 3, dimensi usability adalah dimensi yang memiliki kesesuaian paling tinggi dengan tingkat kesesuaian sebesar $85,00 \%$, hal tersebut mengindikasikan bahwa kualitas layanan website Universitas Tadulako cukup berhasil pada aspek usability. Dimensi dengan tingkat kesesuaian paling rendah adalah dimensi kualitas interaksi layanan sebesar $73,52 \%$, hal tersebut mengindikasikan bahwa kualitas interaksi layanan merupakan aspek yang paling perlu ditingkatkan oleh pihak manajemen pengelola website dalam meningkatkan kualitas layanan website Untad. Besarnya harapan mahasiswa yang telah dipenuhi adalah sebesar $78,17 \%$, dan sebesar $21,83 \%$ belum terpenuhi.

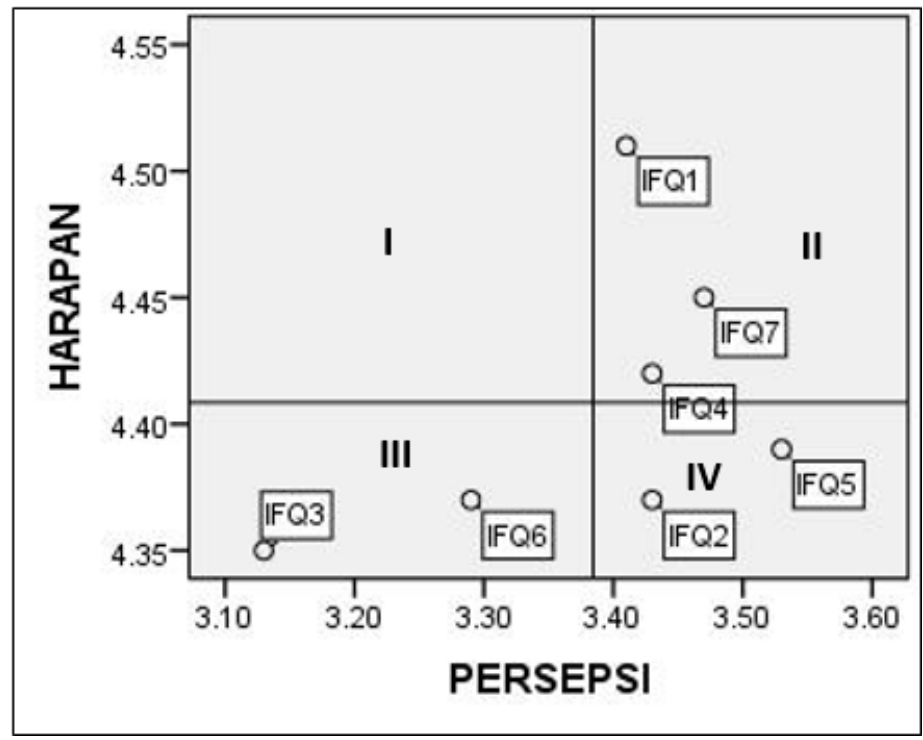

Gambar 2. Diagram kartesius kualitas informasi

Rata-rata dari nilai persepsi dan nilai harapan yang telah diketahui, digunakan untuk menentukan posisi penempatan tiap indikator pada diagram kartesius yang dibagi menjadi empat wilayah yang dibatasi oleh nilai rata-rata seluruh indikator pada tingkat persepsi pada sumbu $X$ dan tingkat harapan pada sumbu Y. Atribut yang berada dalam kuadran I (Concentrate Here) dianggap sangat penting bagi pengguna, tetapi memiliki tingkat kinerja yang cukup rendah. Hal ini mengirimkan pesan langsung bahwa upaya perbaikan harus difokuskan pada kuadran ini (Keong, 2014). Atribut yang berada dalam kuadran II (Keep up The Good Work) dianggap sangat penting untuk pengguna, dan pada saat yang bersamaan, layanan dianggap memiliki tingkat kinerja yang tinggi (Chu \& Choi, 2000). Aktivitas pada kuadran Keep up The Good Work telah dilaksanakan dengan baik, dan penyedia layanan harus menjaga kinerjanya (Jairak \& Praneetpolgrang, 2013). Atribut yang berada dalam kuadran III Pengukuran kualitas layanan website Universitas Tadulako menggunakan ... (C) 2018 Register: Jurnal IImiah Teknologi Sistem Informasi. Semua hak cipta dilindungi undang-undang. 
(Low Priority) dianggap memiliki kepentingan dan kinerja yang relatif rendah. Penyedia layanan harus membatasi sumber daya untuk semua kegiatan yang berada dalam kuadran ini (Jairak \& Praneetpolgrang, 2013). Atribut yang berada dalam kuadran IV (Possible Overkill) dianggap kurang penting oleh pengguna, namun layanan dianggap memiliki kinerja yang baik (Silva \& Fernandes, 2011). Dalam situasi ini, penyedia layanan harus mengalokasikan lebih banyak sumber daya untuk menangani atribut yang berada pada kuadran Concentrate Here (Wong, Hideki, \& George, 2011).

Gambar 2, Gambar 3, Gambar 4 dan Gambar 5 adalah penempatan masing-masing indikator masing-masing dimensi dalam importance performance matrix (diagram kartesius). Berdasarkan diagram kartesius pada Gambar 2 terlihat letak masing-masing indikator pada dimensi kualitas informasi. Dari tujuh indikator dalam dimensi kualitas informasi, terdapat tiga indikator yang berada yang berada dalam kuadran II yaitu IFQ1 (website menyediakan informasi yang akurat), IFQ4 (website menyediakan informasi yang relevan), dan IFQ7 (website menyajikan informasi dalam format yang tepat). Indikator yang termasuk dalam kuadran II dianggap sangat penting untuk mahasiswa dan pada saat yang bersamaan, layanan ini dianggap memiliki tingkat kinerja yang baik dan telah terlaksana dengan baik, sehingga pihak manajemen pengelola website harus menjaga masing-masing kinerja indikator tersebut.

Indikator IFQ3 (website menyediakan informasi tepat waktu) dan IFQ6 (website menyediakan informasi yang detail) memiliki nilai persepsi dan harapan yang rendah sehingga terletak dalam kuadran III, yang mengindikasikan bahwa indikator ini tidak terlalu dianggap penting oleh mahasiswa. Pihak manajemen pengelola website sebaiknya membatasi sumber daya untuk indikator ini. Dalam kuadran IV, indikator IFQ2 (website menyediakan informasi yang terpercaya) dan IFQ5 (website menyediakan informasi yang mudah dimengerti), memiliki nilai harapan rendah, namun indikator tersebut dianggap memiliki kinerja yang baik dilihat dari nilai persepsi yang tinggi.

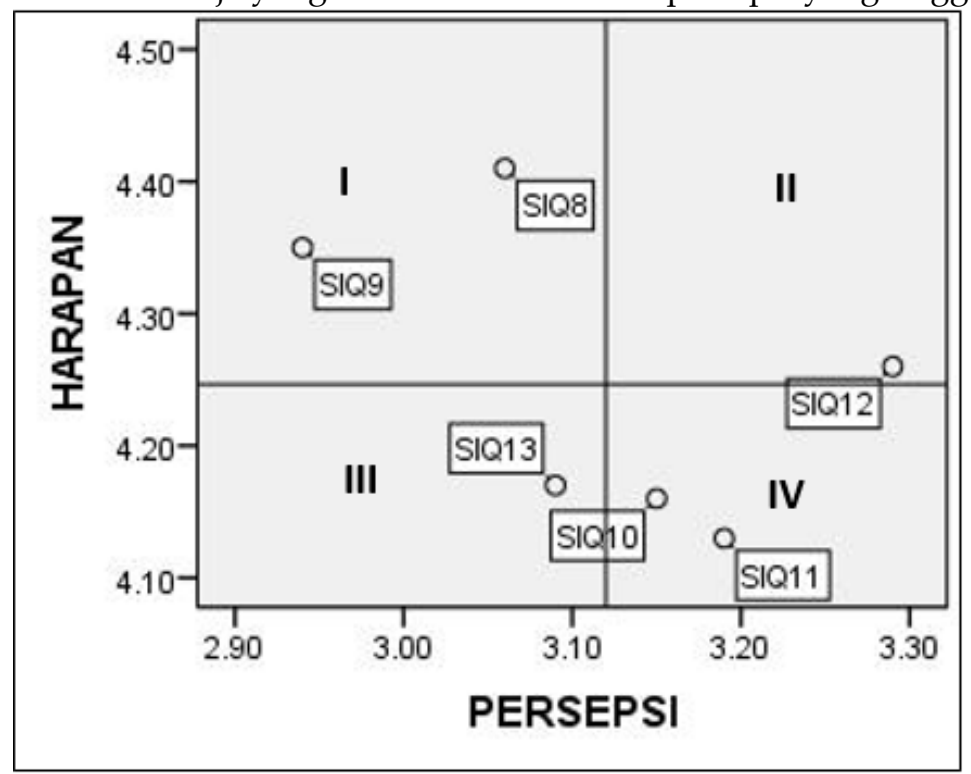

Gambar 3. Diagram Kartesius Kualitas Interaksi Layanan

Berdasarkan diagram kartesius pada Gambar 3 terlihat letak masing-masing indikator pada dimensi kualitas interaksi layanan. Terdapat dua indikator yang termasuk dalam kuadran I yaitu pengguna merasa aman ketika melakukan transaksi (SIQ8) dan saya merasa aman terhadap informasi pribadi yang diminta website (SIQ9). Indikator yang berada dalam kuadran I dianggap sangat penting oleh mahasiswa karena memiliki nilai harapan tinggi, tetapi kinerja indikator tersebut masih rendah dilihat dari nilai persepsi yang rendah. Dengan demikian, indikator yang berada dalam kuadran I merupakan prioritas utama untuk diadakan upaya perbaikan lebih lanjut.

Dalam kuadran II, Indikator website memberikan kemudahan untuk berkomunikasi dengan universitas (SIQ12) dianggap sangat penting untuk mahasiswa dan pada saat yang bersamaan, layanan ini dianggap memiliki tingkat kinerja yang baik dan telah terlaksana dengan baik, sehingga pihak manajemen pengelola website harus menjaga kinerja indikator SIQ12.

Kuadran III mencerminkan tingkat persepsi dan harapan yang rendah. Berdasarkan hasil analisis data, indikator SIQ13 (saya menerima layanan sesuai yang dijanjikan website) berada dalam kuadran ini, yang mengindikasikan bahwa indikator ini tidak terlalu dianggap penting oleh mahasiswa. 
Dalam kuadran IV, indikator SIQ10 (website memiliki ruang untuk personalisasi) dan SIQ11 (website memiliki ruang untuk komunitas) memiliki nilai harapan rendah, namun layanan dianggap memiliki kinerja yang baik berdasarkan tingkat persepsi yang dinilai tinggi.

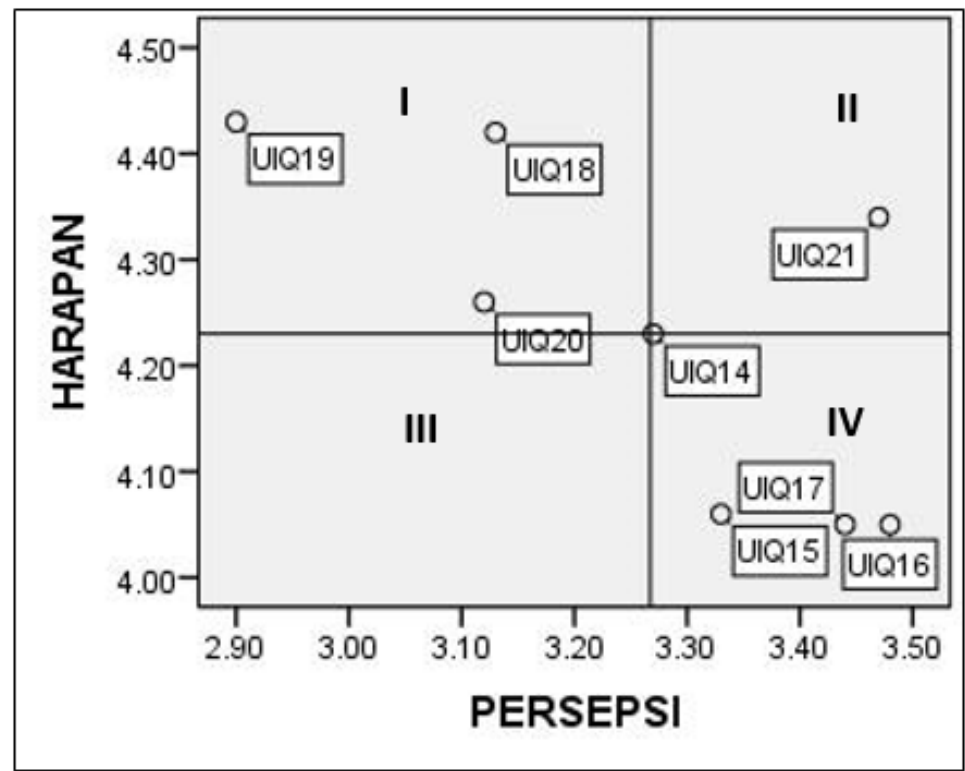

Gambar 4. Diagram Kartesius Kualitas Antarmuka Pengguna

Berdasarkan diagram kartesius pada Gambar 4 terlihat letak masing-masing indikator pada dimensi kualitas antarmuka pengguna. Indikator yang berada dalam kuadran I dianggap sangat penting oleh mahasiswa karena memiliki nilai harapan tinggi, tetapi kinerja indikator tersebut masih rendah dilihat dari nilai persepsi yang rendah. Dengan demikian, indikator yang berada dalam kuadran ini merupakan prioritas utama untuk diadakan upaya perbaikan lebih lanjut. Terdapat empat indikator yang termasuk dalam kuadran I yaitu UIQ14 (website menggunakan gambar yang tepat), UIQ18 (Link pada website bekerja dengan baik), UIQ19 (proses download yang cepat), dan UIQ20 (website memiliki tata letak yang terstruktur dan konsisten).

Indikator UIQ21 (website mencerminkan identitas universitas) terletak pada kuadran II, menunjukkan bahwa indikator ini dianggap sangat penting untuk mahasiswa dan pada saat yang bersamaan, layanan ini dianggap memiliki tingkat kinerja yang baik dan telah terlaksana dengan baik, sehingga pihak manajemen pengelola website harus menjaga kinerja indikator UIQ21.

Kuadran III memiliki tingkat persepsi dan harapan yang rendah yang mengindikasikan bahwa indikator didalamnya tidak terlalu dianggap penting oleh mahasiswa. Berdasarkan hasil analisis data, tidak ada indikator yang berada dalam kuadran III.

Dalam kuadran IV, indikator UIQ15 (website menggunakan font (huruf) yang sesuai), UIQ16 (website menggunakan warna yang sesuai), dan UIQ17 (website menggunakan desain halaman yang sesuai) memiliki nilai harapan rendah, namun layanan dianggap memiliki kinerja yang baik berdasarkan tingkat persepsi yang dinilai tinggi.

Berdasarkan diagram kartesius pada Gambar 5 terlihat letak masing-masing indikator pada dimensi usability. Pada kuadran I, indikator USQ22 (saya dengan mudah dapat belajar menggunakan website) dan USQ23 (interaksi dengan website jelas dan dapat dimengerti) dianggap sangat penting oleh mahasiswa karena memiliki nilai harapan tinggi, tetapi kinerja indikator tersebut masih rendah dilihat dari nilai persepsi yang rendah. Dengan demikian, indikator USQ22 dan USQ23 merupakan prioritas utama untuk diadakan upaya perbaikan lebih lanjut.

Pada kuadran II, indikator USQ25 (website mudah digunakan) dianggap sangat penting untuk mahasiswa dan pada saat yang bersamaan, layanan ini dianggap memiliki tingkat kinerja yang baik dan telah terlaksana dengan baik, sehingga pihak manajemen pengelola website harus menjaga kinerja indikator tersebut.

Pada kuadran III, indikator USQ24 (website mudah dinavigasi) dan USQ28 (website memiliki tampilan keseluruhan yang menarik) dianggap memiliki nilai persepsi dan harapan yang rendah, yang mengindikasikan bahwa indikator ini tidak terlalu dianggap penting oleh mahasiswa. Pihak 
manajemen pengelola website sebaiknya membatasi sumber daya untuk indikator ini. Pada kuadran IV, indikator USQ26 (website mengandung nilai kompetensi) dan USQ27 (website menciptakan pengalaman positif bagi saya) mencerminkan tingkat harapan rendah dan tingkat persepsi tinggi.

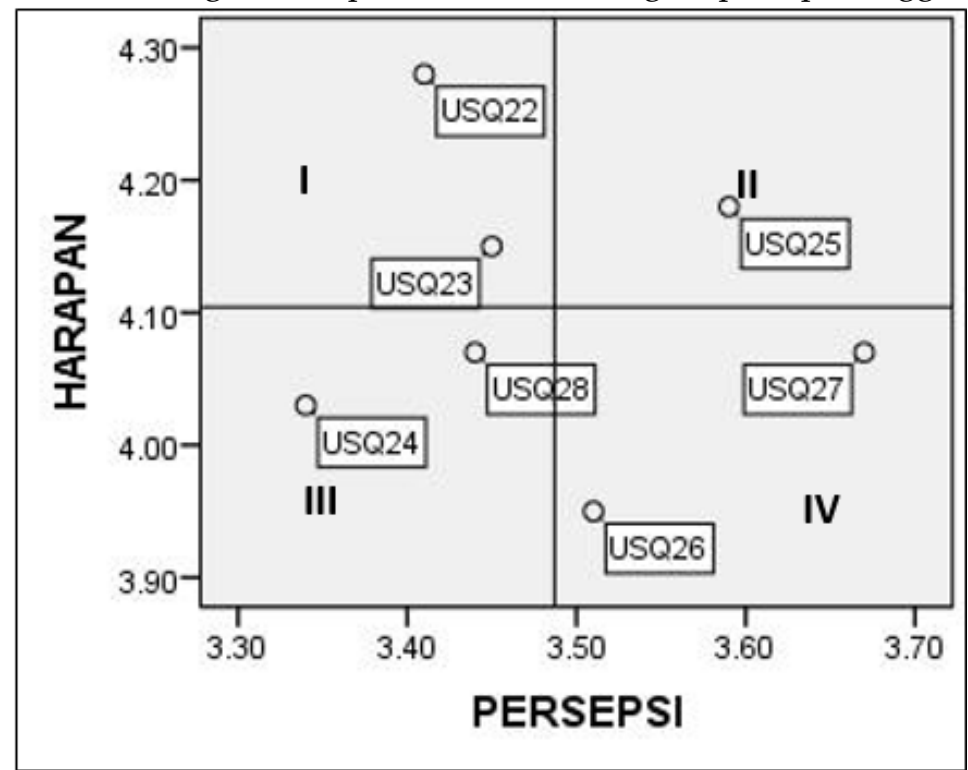

Gambar 5. Diagram Kartesius Usability

Hasil pemetaan dalam diagram kartesius pada masing-masing dimensi kualitas website dengan teknik IPA dalam penelitian ini dapat dijadikan umpan balik (feedback) bagi pihak manajemen pengelola website Untad dalam menyusun strategi untuk meningkatkan kualitas website Untad. Adapun saran yang diberikan adalah sebagai berikut:

1. Pihak manajemen pengelola website Untad perlu untuk mempertahankan prestasi yang telah dicapai, dalam hal ini yaitu kualitas informasi yang umumnya tingkat pelaksanaannya telah sesuai dengan harapan mahasiswa.

2. Usability (kegunaan) website Untad dalam pelaksanaannya layanan dianggap memiliki kinerja yang baik tetapi dianggap tidak terlalu penting oleh mahasiswa. Dalam situasi ini, pihak manajemen pengelola website perlu mengalokasikan lebih banyak sumber daya untuk mengelola kualitas interaksi layanan karena dianggap memiliki kinerja yang rendah.

Berdasarkan hasil diagram IPA, pihak manajemen pengelola website harus fokus pada setiap indikator-indikator dari masing-masing dimensi kualitas website yang berada pada kuadran I "Persepsi Rendah, Harapan Tinggi" karena indikator-indikator tersebut dianggap sangat penting oleh mahasiswa, namun memiliki tingkat kinerja yang rendah. Dengan demikian, indikator-indikator tersebut merupakan prioritas utama untuk diadakan upaya perbaikan lebih lanjut.

\section{Kesimpulan}

Beberapa kesimpulan yang bisa diberikan dari hasil penelitian ini adalah: 1) Hasil penelitian menunjukkan bahwa tingkat kualitas layanan website Universitas Tadulako belum sesuai dengan harapan mahasiswa. Hal ini terbukti dari adanya perbedaan rata-rata antara persepsi dengan harapan ideal mahasiswa terhadap masing-masing dimensi website; 2) Hasil penelitian menunjukkan bahwa semuagap bernilai negatif, dimana persepsi lebih kecil dibandingkan dengan harapan mahasiswa.gap paling kecil terletak pada dimensi usability yang mengindikasikan bahwa layanan website Untad cukup berhasil pada kualitas usability.gap paling besar terletak pada dimensi kualitas interaksi layanan yang mengindikasikan bahwa layanan website Universitas Tadulako yang belum memenuhi harapan ideal mahasiswa terutama dari kualitas interaksi layanan; 3) Bagi pihak manajemen website universitas tadulako, hasil penelitian ini bisa dijadikan acuan untuk mengembangkan website yang lebih baik. Pengembangan bisa difokuskan kepada indikator-indikator yang berada pada kuadran I yaitu: pengguna merasa aman ketika melakukan transaksi, pengguna merasa aman terhadap informasi pribadi, Link pada website bekerja dengan baik, kecepatan download pada halaman website, website memiliki tata letak yang terstruktur dan konsisten, pengguna dengan mudah dapat belajar 
menggunakan website, dan interaksi pengguna dengan website jelas dan dapat dimengerti.

Adapun penelitian yang dapat dilakukan di masa yang akan datang adalah: 1) Penelitian yang akan datang diharapkan lebih mengarah kepada evaluasi kualitas antarmuka pengguna (user interface quality) website tidak hanya dari sudut pandang mahasiswa, tetapi juga melibatkan web desainer atau pihak manajemen pengelola website; 2) Penelitian dengan kajian yang sama disarankan untuk lebih mengembangkan lagi variabel penelitian yang digunakan dengan jumlah sampel yang lebih besar dan responden penelitian tidak hanya berasal dari mahasiswa, tetapi juga melibatkan dosen dan pegawai serta pengunjung umum website.

\section{Referensi}

Arifin, S. R. (2015). Analisis kualitas layanan website Universitas Hasanuddin dengan metode WebQual 4.0 modifikasi. Yogyakarta: Universitas Gadjah Mada.

Bakri, T. (2016, Februari 4). Versi Kemenristek Dikti Untad Peringkat ke-35, PTN Terbaik Ketiga di Kawasan Timur Indonesia. Retrieved from Universitas Tadulako: . https:/untad.ac.id/versikemenristek-dikti-untad-peringkat-ke-35-ptn-terbaik-ketiga-di-kawasan-timur-indonesia/

Barnes, S. J., \& Vidgen, R. (2003). Measuring web site quality improvements: a case study of the forum on strategic management knowledge exchange. Industrial management \& Data systems, 103(5), 297 309.

Barnes, S. J., \& Vidgen, R. T. (2002). An integrative approach to the assessment of e-commerce quality. Journal of Electronic Commerce Research, 3(3), 114-127.

Barnes, S. J., \& Vidgen, R. T. (2005). Data triangulation in action: using comment analysis to refine web quality metrics. European Conference on Information Systems (ECIS) 2005 Proceedings (p. 24). Regensburg: AIS Electronic Library (AISeL).

Chu, R. K., \& Choi, T. (2000). An importance-performance analysis of hotel selection factors in the Hong Kong hotel industry: a comparison of business and leisure travellers. Tourism management, 21(4), 363-377.

Dikti, D. J. (2018, Agustus 18). Daftar 100 Peringkat Perguruan Tinggi Non-Politeknik di Indonesia tahun 2017. Retrieved from Direktorat Jenderal Kelembagaan Iptek dan Dikti: http://kelembagaan.ristekdikti.go.id/index.php/2017/08/18/daftar-100-peringkat-perguruan-tingginon-politeknik-tahun-2017/

Hasan, L. (2014). Evaluating the usability of educational websites based on students' preferences of design characteristics. International Arab Journal of e-Technology, 3(3), 179-193.

Jairak, K., \& Praneetpolgrang, P. (2013). Applying IT governance balanced scorecard and importanceperformance analysis for providing IT governance strategy in university. Information Management \& Computer Security, 21(4), 228-249.

Jannah, E. N., \& Arifin, A. Z. (2015). Sistem Informasi Absensi Haul Berbasis Web di Pondok Pesantren Muhyiddin Surabaya. Register: Jurnal Ilmiah Teknologi Sistem Informasi, 1(1), 47-59.

Keong, W. E. (2014). The Use of Importance-performance Analysis (IPA) in Evaluating Web 2.0 Technologies in Malaysian Retail-chain Business. Sains Humanika, 2(3), 67-73.

Kesuma, D. P. (2014). Analisis Pengukuran Kualitas Layanan Web Perguruan Tinggi XYZ Menggunakan Servqual. Seminar Nasional Informatika 2014 (pp. 178-183). Yogyakarta: Universitas Pembangunan Nasional "Veteran" Yogyakarta.

Monalisa, S. (2016). Analisis Kualitas Layanan Website Terhadap Kepuasan Mahasiswa dengan Penerapan Metode Webqual (Studi Kasus : UIN Suska Riau). Jurnal Sains, Teknologi dan Industri, 13(2), 181-189.

Peng, L. K., Ramaiah, C. K., \& Foo, S. (2004). Heuristic-based user interface evaluation at Nanyang Technological University in Singapore. Program, 38(1), 42-59.

Silva, F. H., \& Fernandes, P. O. (2011). Importance-performance analysis as a tool in evaluating higher education service quality: the empirical results of ESTiG (IPB). In The 17th International Business Information Management Association Conference (pp. 306-315). Milan: University of Pavia.

Siregar, S. (2013). Statistik Parametrik untuk Penelitian Kuantitatif. Jakarta: Bumi Aksara. 
Sujono, S., \& Santoso, H. B. (2017). E-Learning Quality Analysis Of Use Of Web Conference In The Improvement Of Students With Learning Method Webqual (Case Study: Universitas KH. A. Wahab Hasbullah). IEESE International Journal of Science and Technology (IJSTE), 6(1), 8-14.

Sutcliffe, A. (2001). Heuristic evaluation of website attractiveness and usability. In 8th International Workshop on design, specification, and verification of interactive systems (pp. 183-198). Berlin: Springer.

Tadulako, U. (2015, September 1). Untad Luncurkan SIAKAD Mobile. Retrieved from Universitas Tadulako: https://untad.ac.id/untad-luncurkan-siakad-mobile/

Tarigan, J. (2008). User satisfaction using Webqual instrument: A research on stock exchange of Thailand (SET). Jurnal Akuntansi dan Keuangan, 10(1), 34-47.

Wong, M. S., Hideki, N., \& George, P. (2011). The use of importance-performance analysis (IPA) in evaluating Japan's e-government services. Journal of Theoretical and Applied Electronic Commerce Research, 6(2), 17-30. 